\title{
The Islamic Knowledge Approach as a Qualitative Data Analysis Method in Islamic-Based Research
}

Kasimah Binti Kamaruddin, Mohd Shukri Bin Hanapi

To Link this Article: http://dx.doi.org/10.6007/IJARBSS/v11-i2/8661

DOI:10.6007/IJARBSS/v11-i2/8661

Received: 12 December 2020, Revised: 13 January 2021, Accepted: 23 January 2021

Published Online: 13 February 2021

In-Text Citation: (Kamaruddin \& Hanapi, 2021)

To Cite this Article: Kamaruddin, K. B., \& Hanapi, M. S. B. (2021). The Islamic Knowledge Approach as a Qualitative Data Analysis Method in Islamic-Based Research. International Journal of Academic Research in Business and Social Sciences, 11(2), 186-194.

Copyright: (c) 2021 The Author(s)

Published by Human Resource Management Academic Research Society (www.hrmars.com) This article is published under the Creative Commons Attribution (CC BY 4.0) license. Anyone may reproduce, distribute, translate and create derivative works of this article (for both commercial and non-commercial purposes), subject to full attribution to the original publication and authors. The full terms of this license may be seen at: http://creativecommons.org/licences/by/4.0/legalcode

Vol. 11, No. 2, 2021, Pg. 186 - 194

Full Terms \& Conditions of access and use can be found at http://hrmars.com/index.php/pages/detail/publication-ethics 


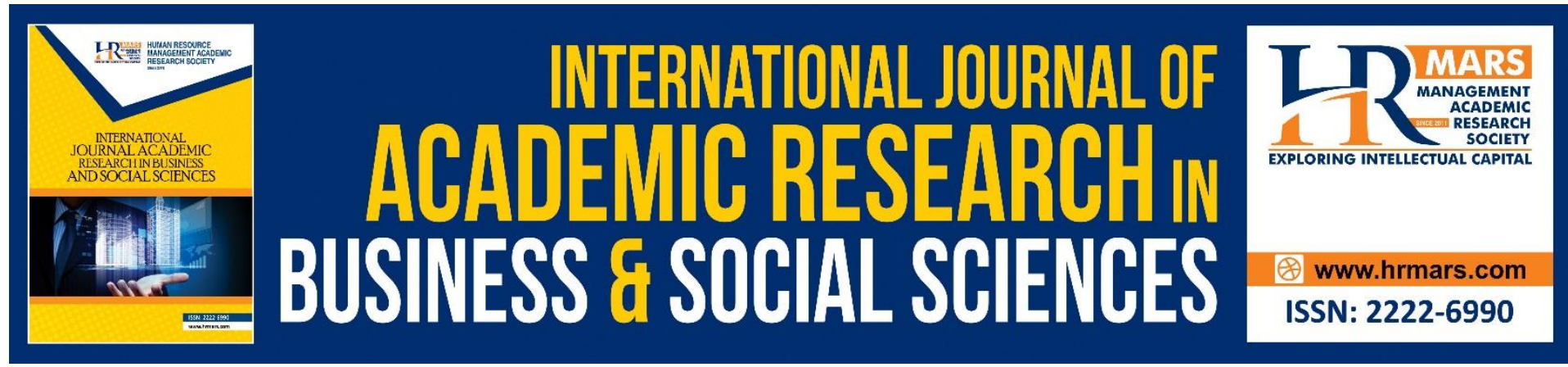

\title{
The Islamic Knowledge Approach as a Qualitative Data Analysis Method in Islamic-Based Research
}

\author{
Kasimah Binti Kamaruddin, Mohd Shukri Bin Hanapi \\ Universiti Sultan Zainal Abidin, Gong Badak Campus, 21300 Kuala Terengganu. Malaysia. \\ Intitute of Islamic Development, Universiti Sains Malaysia, Pulau Pinang, Malaysia
}

\begin{abstract}
The qualitative data analysis is an important component in conventional research method (CRM) and also Islamic-based research Method (IBRM) methods. The qualitative data analysis method is inappropriate when used as an IBR method because it lacks elements of tasawur, epistemology and analytical tools. Hence, what is deficient in the qualitative data analysis method and is Islamic knowledge suitable as an Islamic-based qualitative research method. This study intended to identify the deficiencies in the qualitative data analysis method and review literature related to the use of Islamic knowledge as an Islamic-based qualitative research method. This qualitative study collected data from previous studies related to the Islamic-based research method and analysed the data using the dilalah analysis method. Findings show that methods in the usul al-figh, Hadith and tafsir, which are constituents of Islamic knowledge, should be highlighted as data analysis methods in Islamic-based research. Keywords: Data Analysis Method, Conventional Research Method, Islamic-Based Research Method, Islamic Knowledge
\end{abstract}

\section{Introduction}

In-depth and pertinent discussions related to the findings of a study can only be supported by analysing data in an accurate and detailed manner. Data will not provide any useful information about a problem if it is not analysed using certain methods (Konting, 1990:309) as well as not based on research questions that intend to explain the objectives of the study (Awang, 2009:94; Bakar, 2007:1). Hence, a qualitative data analysis should be systematically conducted. However, the researcher could prefer a different data analysis method. Actually, there is no one qualitative data analysis method that is unanimously accepted by all researchers. This method usually leads to findings by qualitative studies that are frequently questioned regarding its validity and credibility (Chua, 2006:47). The dominant data analysis method applied in contemporary studies is the conventional data analysis method, which comprises content analysis, theme analysis, narrative analysis, discourse analysis, semiotic analysis (Liamputtong, 2009:469; Sekaran \& Bougie, 2013:302), textual analysis and hermeneutic analysis (Chua, 2006:47-49) methods. The question is whether it is appropriate to use the conventional data analysis method for studies related to Islam and Muslims. Looking at the deficiencies in the conventional data analysis method, this study found that it 
would be appropriate to highlight Islamic knowledge, which could be a more appropriate data analysis method for studies related to Islam and Muslims in a KPBI qualitative data analysis.

\section{Status of the Qualitative Data Analysis in CRM}

According to Salleh (2008:134), the need to find an alternative to the conventional data analysis method is due to the deficiencies in the method itself. The deficiencies in this context refer to the differences in the method's epistemology and philosophy compared to that of the Islamic research method. Western epistemology and philosophy is solely based on concepts, whereas Islamic epistemology and philosophy is based on Islamic sources, such as the al-Qur'an, Hadith, Ijmak (consensus of Islamic scholars or the Prophet's SAW companions) and Qiyas (analogical reasoning). There are several leading qualitative data analysis methods used today to analyse data related to Islamic and Muslim studies, including studies in the form of decrees that use justifications or evidence (dalil) mentioned in the al-Qur'an and Hadith. Some of these methods are the content analysis, theme analysis, narrative analysis, discourse analysis, semiotic analysis (Liamputtong, 2009:469; Sekaran \& Bougie, 2013:302), textual analysis and hermeneutic analysis (Chua, 2006:47-49) methods. Thus, according to Khairuldin and Ibrahim (2017), with the various shortcomings in the system of social research that are used today, a study should be conducted in order to establish a research methodology which are based on Islam.

However, according to Salleh (2010:136), there are at least three reasons why the CRM is incomplete from the analytical tools' aspect. First, the CRM can only collect information through observations, existing data or information and analysis on interactions among variables. This scientific aspect can only examine matters that are tangible in nature. In addition, Salleh (2010:136-138) asserted that a research analytical tool should be able to examine and analyse both, tangible and intangible matters, and only then can it be holistic and capable of understanding problems, make conclusions and identify accurate solutions. For example, the shortcomings of the content analysis method are that its implementation first requires the determination of the document's validity and credibility to ensure that the eventual findings are authentic (Bryman, 2012: Babbie \& Rubin, 2014:460). Data obtained is limited to tangible data that can be assessed by the human senses. Besides that, tangible data sometimes cannot provide an understanding of the matters at hand and are unable to answer some of the questions put forth (Babbie, 20003: 325). Next, the content analysis method contains certain problems that could arise when the implicit content is considered instead of the explicit content (Bryman, 2012: 306-307).

Second, CRM only examines and presumes that reality can only be illuminated by nazari knowledge and 'aqli dalil, and not with daruri knowledge and naqli dalil. Both the former is lower in rank or position compared to the latter, which is namely daruri knowledge and naqli dalil. Third, since KPL only uses nazari knowledge and 'aqli dalil, hence, the level of validity attained would only be at the 'ayn al-yaqin stage, in which the validity as evidence or proof is basically dependent only on the human senses, whereas the highest stage is the 'ilm al-yaqin stage, which is validity based on experience and knowledge acquired from research and the rational interpretation of data as well as findings. However, it is unable to reach the highest validity stage, which is the haq al-yaqin stage (Salleh, 2008:134). 


\section{The Islamic Knowledge Approach as a Qualitative Data Analysis in IBRM}

IBRM development has been a phenomenon these days. These researches examine various aspects of life in an Islamic perspective (Khairuldin, 2017). IBRM is a research method from an Islamic social science perspective that was formed based on Islamic turath knowledge like akidah, usul al-figh, the figh method, the fatwa process, Hadith, tafsir, tajwid and qiraat (Hassan, 2017). Several studies have shown the suitability of Islamic knowledge for designing the KPBI data analysis method. Islamic knowledge that has been studied and found to be a suitable data analysis method are the usul al-fiqh, tafsir and Hadith analysis methods.

\section{Usul al-Fiqh}

Several studies have focused on usul al-figh as a data analysis method (Majid, 2009; Miswan, 2014; Asni, 2017; Hassan, 2018 \& Kamaruddin, 2020). Majid (2009) adduced several applications of the usul figh method as a data analysis method. First, the text analysis method that is widely used under the title 'qawa'id al-tafsir' for interpretating decrees mentioned in the al-Qur'an and al-Sunnah. Second, the qiyas mechanism can be applied as a comparative analysis method for ijtihad purposes in cases that do not involve the determination of Islamic law (arbitration, judgment, authority or God's will) based on the al-Qur'an, Hadith or ijmak. Miswan (2014) had examined the appropriateness of applying the dilalat method in usul alfiqh as a data analysis method in Islamic research. He emphasised on two dilalat methods, namely mafhum muwafaqat and mafhum mukhalafat, whereby its application could analyse implicit and explicit verses found in the texts.

Asni (2017), in his analytical study, elaborated on the usul al-figh method used by al-Syatibiy. He chose al-Syatibiy because al-Syatibiy is a famous ulama in the field of Islamic law. Among the methods that were analysed were the al-amr al-nahiy, mafhum muwafaqat and alta'arud baina al-adillat methods. The study found that the main element adopted by alSyatibiy in efforts to consolidate the usul al-fiqh method was the use of the maqasid alsyari'at concept. Hence, the theory adduced by al-Syatibiy was found to be appropriate when applied in the fatwa issuing process in Malaysia. Besides that, Hassan (2018) had highlighted the tarjih analysis method. There are two techniques used in the tarjih analysis method, which is tarjih baina al-nusus used as a screening technique and tarjih baina al-aqsiyat as a data comparison technique.

Hassan (2018) also adduced a data analysis method based on the dilalat verification method. Studies by Miswan (2014) and also Hassan (2018) had explored the dilalat analysis method. These studies emphasised that the dilalat analysis method is appropriate for analysing texts related to Islam and Muslims compared to the textual and content analysis methods that were used previously; moreover, the sections of dilalat are bigger and wider compared to the KPL textual analysis. The KPL content analysis method is divided into two forms, namely the explicit and implicit content forms. Hence, a data analysis that uses the dilalat textual analysis method can enhance the researcher's confidence in the accuracy and clarity of the data, specifically studies related to Islam. Miswan (2014) adduced several stages in the dilalat data analysis, such as identifying the relevant statements, interpreting the statement and classifying the statement according the context of the discussions, forming the thematic method and the general concept as well as systematically arranging the method, theme and concept. According to Safi (1998) and Miswan (2013), there are four steps in analysing texts found in the divine revelation or other sources by using the mafhum element. First, identifying 
relevant statements related to the KPBI data analysis method; second, interpret the selected document related to the IRBM data analysis method; third, thoroughly explain the IRBM data analysis method; and fourth, establish an appropriate and systematic data analysis method.

Kamaruddin (2020) elaborated on the usuliyyah al-lughawiyyah method as a law data analysis method in IBRM. There are three phases in the law analysis method by Kamaruddin (2020). The first phase is the pre-analysis phase that determines the use of lafz in a meaning, the position of lafz in a meaning and the indicator of lafz in a meaning. The second phase is the analysis phase that uses the indicator of lafz in a meaning and the last phase is the conclusion of the analysis phase. All three phases are used to analyse law verses in order to produce law that are according to syarak.

\section{Tafsir}

In regard to tafsir knowledge, Hanapi (2014) had studied the appropriateness of applying the al-mufassirin method when analysing data in a study related to Islam. The tafsir technique comprises the ijmaliy, tafsiliy, al-muqarran and al-maudhu'iyy methods. Studies related to the tafsir technique had touched on the position of this technique in data analysis (Embong, 2017; Hanapi \& Embong, 2017). The studies found that analysing research data and the tafsir technique have three similarities, namely elaborating and describing data, the established systematic procedures and answers to research questions as well as the research objectives. Hence, the data analysis method found in the tafsir technique, namely the al-tahliliy, alijmaliy, al-muqaran and al-mawdu'iy methods, can be applied in the Islamic research data analysis method. This study shows that the tafsir technique is appropriate when applied in studies related to Islam and it can be divided into three main components, namely the research design as well as the data collection and analysis methods.

\section{Hadith}

Regarding the Hadith, Hanapi (2015) examined the al-mawdhu'iy Hadith technique used by muhaddithin when elaborating on the Prophet's SAW hadith and discussing the appropriateness of applying the technique in studies related to Islam. The suitability is based on two aspects, namely the rating of sources and data analysis aspects. There are four steps involved in the text analysis method based on the al-mawdhu'iy method, such as establishing the title and themes, dividing the texts, arranging discussions and analyses according to a framework as well as analysing it based on the main sources of Islamic knowledge.

\section{Analysing Islamic Knowledge as a Qualitative Data Analysis in IBRM}

Based on the literature review, there were three main aspects of Islamic knowledge that were highlighted as a IBRM data analysis method, namely Usul al-Fiqh, Tafsir and Hadith. Although the IBRM data analysis method is inadequate for analysing studies related to Islam and Muslims, it is important that this method is highlighted in order to enlighten Islamic researchers on the need to study more aspects of Islamic knowledge to be used as a IBRM data analysis method.

As for usul al-fiqh, the methods highlighted were related to al-amr, al-nahiy, mafhum mukhalafah, al-ta'arud baina al-adillah,_tarjih, dilalah (mafhum muwafaqah and mafhum mukhalafah), qawa'id al-tafsir, qiyas and usuliyyah al-lughawiyyah methods. The aspects Islamic knowledge highlighted as IBRM data analysis methods can be applied for analysing 
IBRM data, for example the mantuq, mafhum muwafaqat and mafhum mukhalafat methods that analyse data, either implicit or explicit, found in a text. This method is better suited for analysing data related to Islam and Muslims compared to the content or text analysis methods. According to Kamaruddin (2020), usul al-figh is better suited as a IBRM data analysis method due to its ability to rate sources and have an analysis process that is detailed and systematic since it uses specific methods found in usul al-figh. Moreover, usul al-figh can be an appropriate method if it is considered based on three aspects, namely its tasawur, epistemology and analytical tools

As for tafsir knowledge, there are several tafsir methods that can act as a data analysis method, such as al-tahliliy (detailed), al-ijmaliy (general or concise), al-muqaran (comparative) and al-mawdhu'iy (themes or titles), as compared to conventional data analysis methods, such as exploring patents, theoretical analysis, semiotics and content analysis. According to Embong (2007), there are three differing suitability aspects between the tafsir technique and the conventional research data analysis method, namely aspects such as data description, procedure and answering the research questions (objectives). When choosing this method, one should refer to the study's objectives and research questions as well as the tendency of the study.

Meanwhile, for the hadith aspect of Islamic knowledge, it consists of the al-maudhu'iy Hadith method, which is used to establish themes or titles, division of the texts, arranging discussions and analyses in a framework as well as analysing it based on the main sources of Islamic knowledge. Mokhtar (2017) saw the appropriateness of the al-maudhu'iy Hadith approach as a data collection and analysis method based on two justifications. First, the al-maudhu'iy Hadith approach is suitable for research related to Islam because it is the main source of Islam. Second, the al-maudhu'iy Hadith approach functions by identifying, collecting and analysing research data related to Islam, consistent with contemporary developments.

Discussion on the Islamic knowledge approach as a qualitative data analysis method in Islamic-based research is depicted in table 1 below. 
INTERNATIONAL JOURNAL OF ACADEMIC RESEARCH IN BUSINESS AND SOCIAL SCIENCES Vol. 11, No. 2, 2021, E-ISSN: 2222-6990 @ 2021 HRMARS

Table 1: The Islamic Knowledge Approach as a Qualitative Data Analysis Method in Islamic-Based Research

\begin{tabular}{|c|c|c|c|}
\hline Bill. & Researcher & $\begin{array}{l}\text { The Islamic } \\
\text { Knowledge } \\
\text { Approach }\end{array}$ & The Qualitative Data Analysis Method \\
\hline 1. & Majid (2009) & Usul al- Fiqh & Qawa'id Tafsir and Qiyas \\
\hline 2. & $\begin{array}{l}\text { Miswan (2014) and } \\
\text { Hassan (2018) }\end{array}$ & Usul al-Fiqh & $\begin{array}{l}\text { Dilalah (mafhum muwafaqah } \text { and } \\
\text { mafhum mukhalafah })\end{array}$ \\
\hline 3. & Hassan (2018) & Usul al-Fiqh & Tarjih \\
\hline 4. & Asni (2017) & Usul al-Fiqh & $\begin{array}{l}\text { Al-amr and al-nahiy, mafhum } \\
\text { mukhalafah and al-ta'arud baina al- } \\
\text { adillah }\end{array}$ \\
\hline 5. & Kamaruddin (2020) & Usul al-Fiqh & Al-Usuliyyah al-Lughawiyyah \\
\hline 6. & $\begin{array}{l}\text { Hanapi (2013) and Embong } \\
\text { (2016 \& 2017) }\end{array}$ & Tafsir & $\begin{array}{l}\text { Al-ijmaliy, al-tahliliy, tafsiliy, al- } \\
\text { muqarran and al -maudhu'iyy. }\end{array}$ \\
\hline 7. & $\begin{array}{l}\text { Hanapi (2015) and } \\
\text { Mokhtar (2017) }\end{array}$ & Hadith & Hadith al -maudhu'iy: \\
\hline
\end{tabular}

\section{Conclusion}

This study shows that aspects of Islamic knowledge highlighted by previous studies are appropriate if used for analysing data related to studies on Islam and Muslims. This is because there are several shortcomings identified in the qualitative data analysis method from the tasawur, epistemology and analytical tools aspects. Hence, usul al-fiqh comprises several suitable methods, which are the qawa'id tafsir, qiyas, dilalah, tarjih and usuliyyah allughawiyyah methods. Besides that, the Hadith was highlighted because of the maudhu'iy Hadith approach, where as Tafsir was highlighted because of the al-tahliliy, al-ijmaliy, almuqaran and al-mawdhu'iy methods. Therefore, it would be appropriate if these aspects of Islamic knowledge are used as a IRBM qualitative data analysis method compared to the CRM qualitative data analysis method, especially for studies related to Islam and Muslims.

\section{Acknowledgement}

Special appreciation is owed to Universiti Sultan Zainal Abidin (UniSZA), Research Management, Innovation \& Commercialization Centre (RMIC) UniSZA.

\section{Corresponding Author}

Kasimah binti Kamaruddin

Tutor Ph.D Faculty of Islamic Contemporary Studies, Universiti Sultan Zainal Abidin, Gong Badak Campus, 21300 Kuala Terengganu, Terengganu, Malaysia

Email: kasimah4983@gmail.com /kasimah@unisza.edu.my 


\section{References}

Majid, M. Z. A. (2009). Aplikasi Kaedah Usul Fiqh dalam Penyelidikan. Wacana Penyelidikan ISDEV IV pada 13 Disember 2007, Universiti Sains Malaysia, Pulau Pinang.1-7.

Bakar, A. (2007). Kaedah Analisis Data Penyelidikan Ilmiah. Kuala Lumpur: Utusan Publications \& Distributors Sdn. Bhd.

Alias, M. S. (2016). Elemen Tunjang Dalam Wacana Dalam Penyelidikan Bebas Nilai: Analisis Dari Perspektif Islam dalam Mencari Metodologi Penelitian Islam by Pusat Kajian Pembangunan Islami Universitas Jember with Pusat Kajian Pengurusan and Pembangunan Islam (ISDEV).

Awang, I. (2009). Kaedah Penyelidikan : Satu Sorotan. Selangor:Intel Multimedia and Publication.

Pustaka.

Babbie, E. (2005). The Practice of Social Research. CA: Wadswoth Belmont

Braun, V., \& Clarke, V. (2006). Using Thematic Analysis in Psychology. Qualitative Research in Physchology.

Bryman, A. (2008). Social Research Methods. Oxford: Oxford University Press.

Piaw, C. Y. (2006). Kaedah Penyelidikan (Buku 1). Malaysia: McGraw Hill Education (Malaysia) Sdn. Bhd.

Creswell, J. W. (2007). Research Design: Qualitative, Quantitative, and Mixed Methods Approaches. Edisi ke-dua. California: SAGE.

Embong, A. H. (2017). Aplikasi Kaedah tafsir dalam Penyelidikan Berteraskan Islam. Doctoral's Thesis. Centre for Islamic Development Management Studies. Universiti Sains Malaysia.

Grbich, C. (2007). Qualitative Data Analysis: An Introduction. London: Sage

Fairclough, N. (2003). Analyzing Analysis: Practice and Innovation. Sydney: Allen\&Unwin.

Asni, F. H. M. (2017). Al-Syatibi Methodology Analysis in The Unification of Usul al-Fiqh Methods. International Journal of Academic Research in Business and Social Sciences. 7(7), 260-268.

Gibbs, G. R. (2007). Analyzing Qualitative Data. London:Sage.

Gill, R. (2000). 'Discourse Analysis' in M.W.Baeur dan G.Gaskell (eds). Qualitative Researching with Text, Image and sound. London: Sage

Grbich, C. (2007). Qualitative Data Analysis:An Introductions. London:Sage.

Hanapi, M. S. (2014). “Aplikasi Kaedah Mufassirin dalam Penganalisisan Data Penyelidikan Berkaitan Islam, presented at The 7th ISDEV International Islamic Development Management Conference (IDMAC2013): Islamic Research Methodology, Universiti Sains Malaysia, Penang.

Hanapi, M. S. (2015). Tradisi Pemikiran Islam Dalam Metode Penelitian: Tumpuan

Khusus Terhadap Metode Hadith al-Mawduiyy. International Conference on Islamic Development (KIPI 2). Fakultas IImu Sosial dan IImu Politik. Universitas Jember. Indonesia.

Hassan, S.A. (2017). Pembinaan Kaedah Penyelidikan Islam Berdasarkan Disiplin-

Disiplin IImu Dalam Epistemologi Islam Dalam Menemukan Kembali Paradigma Pembangunan Islami, Pusat Kajian Pembangunan Islami Universitas Jember and Pusat Kajian Pengurusan dan Pembangunan Islam (Isdev).

Helder, B. (2011). Textual Analysis. Denmark:Samfundslitteratur. 
Krippendorff, K. (2004). Content Analysis: An Introduction to Its Methodology. California: Sage.

Liamputtong, P., \& Ezzy, D. (2005). Qualitative Research Methods. Oxford Universiti Press: Melbourn.

Mckee, A. (2003). Textual Analysis. A Beginner's Guide.London:SAGE.

Minichiello, V., Aroni, R., \& Hays, T. (2008). In Depth Interviewing: Priciples. Techniques, Analysis. Sydney: Person Education Australia.

Miswan, M. S. M. (2014). Dilalat dalam Kaedah Penyelidikan Berteraskan Islam. Master's Thesis, Centre for Islamic Development Management Studies. Universiti Sains Malaysia.

Kamaruddin, K. (2020). Aplikasi Kaedah Usuliyat al-lughawiyyat dalam Penganalisisan Data Kualitatif Kaedah Penyelidikan Berteraskan Islam. Doctoral's Thesis. Centre for Islamic Development Management Studies. Universiti Sains Malaysia.

Sakirullah, A., \& Mohd, H. (2019). Civil Marriage In The Light Of Fiqh Al-Maqaasid, Nigeria As A Case Study. International Journal Of Academic Research In Business And Social Sciences, 9(4).

Wahab, N., \& Ismail, M. S. (2020). Fiqh Muamalat Islam: Hukum Dalam Sistem Jual Beli Atas Talian (E-Dagang) Dari Sudut Pandangan Fuqaha [Islamic Muamalat Of Fiqh: Legal System In Selling Online (E-Commerce) From The Fuqaha Islamic View]. AL-QIYAM International Social Science and Humanities Journal, 2(1), 24-35.

Konting, M.M. (1990). Kaedah Penyelidikan Pendidikan. Kuala Lumpur: Dewan Bahasa dan Pustaka

Masri, R., Bashir, S., \& Abd Rani, R. (2015). Religio-Hermeneutik Sebagai Model Penyelidikan Dalam Kajian Perniagaan Dan Pengurusan. Jurnal Hadhari: An International Journal. 7, 121-133.

Salleh, M. S. (2008). “Kaedah Penyelidikan Berteraskan Islam: Keperluan, Kedudukan dan Hala Tuju". Pemikir, Bill. 54, Oktober-Disember.page 133-164.

Sekaran, U., \& Bougie, R. (2013). Research Methods For Business: a Skill-Building Approach. United Kingdom: John Wiley\& Scons Ltd.

Silverman, D. (2001). Interpreting Qualitative Research: Method for Analyzing Talk, Text and Interaction. London: Sage.

Khairuldin, W. M. K. F. (2017). Towards the development of Islamic based research methodology, International Journal of Academic Research in Business and Social sciences, 7(2). 450-457.

Khairuldin, W. M. K. F., \& Ibrahim, I. (2017). The construction of research method based on fatwa process: The analysis from the view experts. International Journal of Academic Research in Business and Social sciences, 7(4). 58-69.

Mokhtar, W. K. A. W. (2017). Concept Al-Hadith Al-Mawdhuiy As A Method Of Collecting Anlyzing Research's Data. International Journal of Academic Research in Busineess and Social Sciences. 2 (2), 536-542. 